\title{
Kinetics of native and modified Bowman-Birk soya-bean trypsin inhibitor on growth and enzymes activities of the chick pancreas
}

\author{
BY Z. MADAR* \\ Faculty of Agriculture, Hebrew University of Jersualem, Rehovot, Israel \\ (Received 4 September 1978 - Accepted 2I January 1979)
}

I. The Bowman-Birk soya-bean trypsin inhibitor (BBTI) begins to cause pancreatic enlargement and increased enzymic activity in the pancreas of chicks after a minimum of $7 \mathrm{~d}$ of feeding.

2. The active inhibitory site of BBTI against trypsin is the factor involved in the pancreatic enlargement and increase of pancreatic enzyme activity in chicks.

The feeding of heated soya-bean flour containing active trypsin inhibitors results in pancreatic enlargement and an increase of pancreatic enzyme activity in chicks and rats (Lyman et al. 1962; Gertler \& Nitsan, 1970; Nitsan \& Gertler, 1972; Madar et al. 1974). It was suggested that in the course of digestion, trypsin inhibitor bound the proteolytic enzymes which in effect removed them from the intestine (Lyman et al. 1974). The timing and sequence of events caused by soya-bean trypsin inhibitors is not well understood. All previous studies on chicks were performed only after a minimum of $7 \mathrm{~d}$ of feeding with this inhibitor (Madar et al. 1974; Gertler \& Nitsan, 1970). The present work was carried out with Bowman-Birk soya-bean trypsin inhibitor (BBTI) (Birk, 196I). This inhibitor (BBTI) is double-headed with two independent inhibitory sites, one against trypsin and the other against chymotrypsin (EC 3.4.4.5) (Birk et al. 1967; Odani \& Ikenaka, 1972). The effect of BBTI was checked at different times in order to identify the earliest time of its influence on the pancreas and on body growth of chicks. In addition, this inhibitor was exposed to specific modification and then supplemented to the diet of chicks. The aim was to discover the inhibitory site involved in the effect of BBTI on the pancreas.

\section{MATERIALS AND METHODS}

Assay of BBTI

BBTI was prepared according to Birk \& Gertler (I968). Inhibition of trypsin was determined spectrophotometrically on the substrate $N$-Benzoylarginine-p-nitroanilide in dimethylformamide, at $410 \mathrm{~nm}$, and that of chymotrypsin on the substrate $N$-acetyl-L-tyrosine-pnitroanilide also at $410 \mathrm{~nm}$ (Erlanger et al. 196I; Bundy, 1963). Inhibition was expressed as the percentage decrease in activity of the enzyme.

\section{Modifications of $B B T I$}

Oxidation with performic acid. Performic acid, formed by addition of hydrogen peroxide $(300 \mathrm{ml} / \mathrm{l})$-formic acid $(950 \mathrm{ml} / \mathrm{l})(\mathrm{I}: \mathrm{I}, \mathrm{v} / \mathrm{v})$ was kept at $4^{\circ}$ for I h. A solution of $80 \mathrm{mg}$ BBTI in $5 \mathrm{ml}$ methanol was added with stirring to $4 \mathrm{ml}$ chilled performic acid and the reaction mixture was kept for $24 \mathrm{~h}$ at $4^{\circ}$. A portion of $100 \mathrm{ml}$ distilled water was then added and the solution was freeze-dried. The resulting preparation was designated 'BBTI-Per'.

Maleylation. Maleylation of BBTI was carried out as described by Butler et al. (I968) using $0.14 \mathrm{M}$-Tris buffer, $\mathrm{pH} 8.9$. The maleylated preparation was dialysed swiftly at

\footnotetext{
* Present address: Department of Internal Medicine, School of Medicine, Yale University, New Haven, Connecticut.
} 


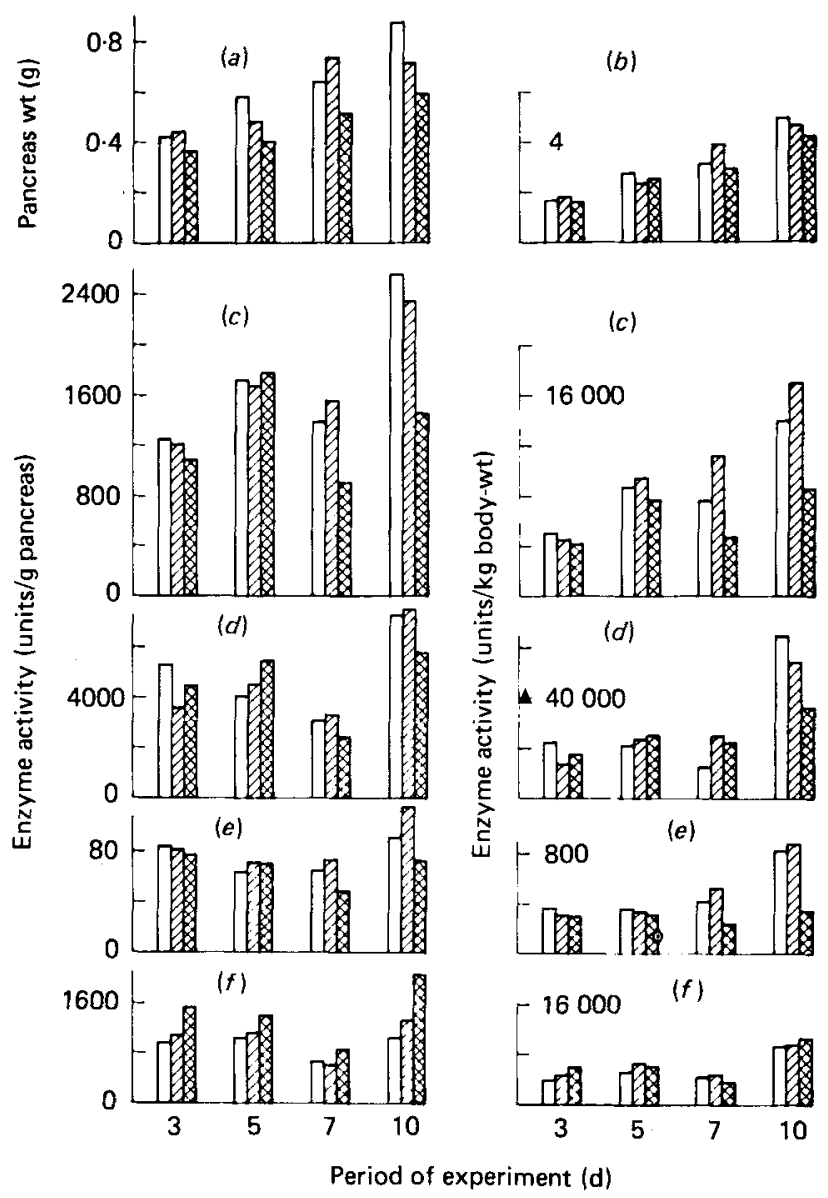

Fig. 1. Effects of raw-soya-bean diet (RSD) ( $\square$ ), heated-soya-bean (HSD) (D), and HSD + Bow. man-Birk trypsin inhibitor (BBTI) (W $)$ on pancreas wcight expressed in $\mathrm{g}(a)$ and $\mathrm{g} / \mathrm{kg}$ bodyweight (b) and on enzymic activity (units/g pancreas, unit $/ \mathrm{kg}$ body-weight) in the pancreas of trypsin $\left(E C_{3.4 .4 .4)}(c)\right.$, chymotrypsin $\left(E C C_{3.4 .4 .5)}(d)\right.$, elastase $\left(E C_{3.4 .4 .7)}(e)\right.$ and amylase ( $E C$ 3 . 2 . I I $)(f)$. Each column represents the mean result for ten chicks. Diets were given for 3, 5, 7 and $10 \mathrm{~d}$, for details, see p. 122. One unit of activity was defined as a change in extinction of 0.0 I extinction at $550 \mathrm{~nm} / 3 \mathrm{~min}$ for amylase, at $410 \mathrm{~nm}$ for trypsin and chymotrypsin. One unit of elastase activity was defined as I $\mu \mathrm{mol}$ substrate hydrolysed during I min at $30^{\circ}$.

$4^{\circ}$ against distilled water and freeze dried. The resulting preparation was designated 'BBTI-Mal'.

Nitration of the inhibitor. Nitration of tyrosine in BBTI was carried out as described by Riordan et al. (1966) using 0.05 M-Tris buffer, $\mathrm{pH} 8$. Separation from the excess of reagents (tetra nitromethane) was carried out by gel filtration on Bio-Gel P-2 column (I0 $\times 200 \mathrm{~mm}$ ) (Biorad Laboratories, 2200, Wright Avenue, Richmond, CA 94804) in a 0.05 M-Tris buffer pH 8. The nitrated preparation was freeze-dried. The result was designated 'BBTI-TNM'.

\section{Biological experiments with chicks}

Expt I. New Hampshire $\times$ White Leghorn male chicks ( ( 20) I d old were divided into three equal groups of forty chicks each, and kept on raw-soya-bean diet (RSD), heated-soyabean diet (HSD) and $\mathrm{HSD}+4 \mathrm{~g} \mathrm{BBTI} / \mathrm{kg}$, as protein source. The composition of the 
Table 1. Effect of different modifications of Bowman-Birk trypsin inhibitor (BBTI) on its ability to inhibit trypsin (EC 3.4.4.4) and chymotrypsin (EC 3.4.4.5)

\begin{tabular}{|c|c|c|}
\hline \multirow[b]{2}{*}{ Inhibitor* } & \multicolumn{2}{|c|}{$\begin{array}{l}\text { Amounts }(\mu \mathrm{g}) \text { of native } \\
\text { and modifed BBTI } \\
\text { which inhibit } 50 \% \text { of } \\
\text { the activity of }\end{array}$} \\
\hline & $\begin{array}{l}\text { Trypsin } \\
(20 \mu \mathrm{g})\end{array}$ & $\begin{array}{l}\text { Chymo- } \\
\text { trypsin } \\
(40 \mu \mathrm{g})\end{array}$ \\
\hline BBTI & $2 \cdot 5$ & 12.5 \\
\hline BBTI-Per & $t$ & $\dagger$ \\
\hline BBTI-Mal & $8 \cdot 0$ & $15 \cdot 5$ \\
\hline BBTI-TNM & 5.0 & 28 \\
\hline
\end{tabular}

* For details, see p. $12 \mathrm{I}$.

$\uparrow$ Inhibition could not be achieved even with a great excess of inhibitor.

experimental diet was as described by Gertler \& Nitzan (1970). At the age of 3,5,7 and I0 d, ten randomly-selected chicks from each group were killed by decapitation. The pancreases were exized immediately, cleaned from fat tissue, weighed and then frozen at $-20^{\circ}$, until assayed for enzyme activity.

Expt 2. Sixty New Hampshire $\times$ White Leghorn male chicks I d old were divided into six groups of ten each. The chicks were kept on a basal diet (Gertler \& Nitsan, I970) supplemented with native and modified BBTI for $7 \mathrm{~d}$. They were killed after a fasting period of $18 \mathrm{~h}$. The pancreases were treated as described previously.

Enzyme assays. The activation of zymogens and the determination of trypsin, chymotrypsin, elastase $\left(E C C_{3.4 .4 .7}\right)$ and $\alpha$-amylase $\left(E C_{3} .2 .1\right.$. I) activities in the pancreas have been described previously (Madar et al. 1974; Madar et al. 1976).

The results were analysed statistically by analysis of variance and multiple range (Snedecor \& Cochran, I967).

\section{RESULTS AND DISCUSSION}

The kinetics of the gain in body-weight, enlargement of the pancreas and the activity of amylase, and proteolytic enzymes in the pancreas as effects of BBTI-feeding are shown in Fig. I. The chicks fed on RSD showed significantly less weight gain $(P<0.0 \mathrm{I})$ than those fed on HSD or HSD + BBTI. This was evident as early as the fifth day of the experiment but there was not yet pancreatic enlargement or increase of enzymic activity. After 7 and $r o d$ on a diet of RSD or HSD + BBTI, the results showed that there was enlargement and increased enzymic activity. These results indicate that the gross noticeable effect of BBTI begins only on the seventh day or perhaps on the sixth day, despite the fact that inhibition of body growth began on the fifth day. Apparently there must be a minimal time, which in this experiment was $7 \mathrm{~d}$, before the inhibitor caused an enlargement of the pancreas and stimulated increased enzymic secretion. This finding confirmed a previous work (Madar \& Klein, 1978), where pancreatic cell changes and increases in their numbers were shown after $7 \mathrm{~d}$ of feeding with RSD. It could not confirm a previous finding with rats which showed the biochemical changes that occurred before the differences in body-weight became evident (Melmed et al. 1976). In addition to this, the present results show that biosynthesis (secretion), especially of proteolytic enzymes occurs at the same time as enlargement; so that it is difficult to detect which actually appeared first, enlargement or increased enzyme activity.

The comparative effects of different modifications on the ability of BBTI to inhibit 


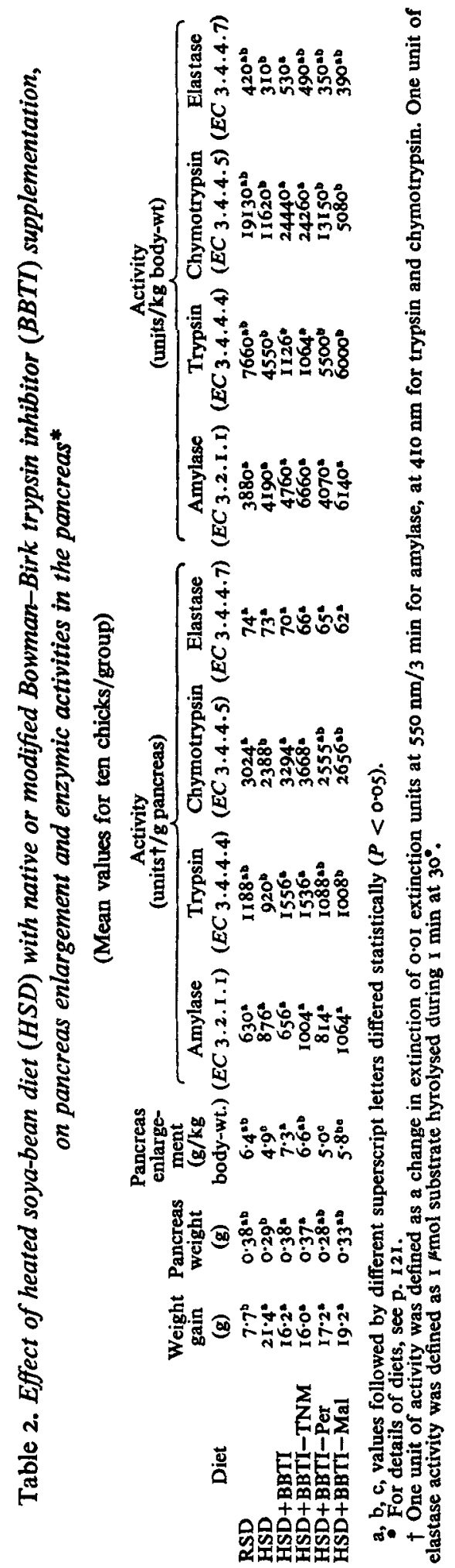


trypsin and chymotrypsin are shown in Table $\mathrm{I}$. The disruption of the S-S bond via oxidation with performic acid (BBTI-Per) resulted in a total loss at the inhibitory potency of BBTI, both towards trypsin and chymotrypsin. This is not surprising in view of the relative abundance of S-S bonds in native BBTI which undoubtedly plays an important role in the conformation of the molecule. The modification with tetra-nitromethane which reacted with the tyrosin residues of BBTI seems to have affected mainly the inhibitory activity against chymotrypsin. This supports earlier findings on the presence of a tyrosine residue in proximity to the active inhibitory site against chymotrypsin (Riordan et al. 1965). On the other hand, maleylation which reacted with lysine residues of BBTI, seems to have affected selectively the inhibitory activity against trypsin. This is in agreement with a previous finding on the presence of a lysine-serine bond in the inhibitory site of BBTI (Birk \& Gertler, 1970).

No growth depression of the chicks was noted (Table 2) upon supplementation of their diet with $4 \mathrm{~g} \mathrm{BBTI} / \mathrm{kg}$ but the enlargement of the pancreas was obvious, as was the situation with RSD. These findings are in agreement with previous studies with rats, chicks and quails (Gertler et al. 1967; Gertler \& Nitsan, 1970; Madar et al. 1974).

Ingestion of HSD diets supplemented with BBTI-Per BBTI-Mal did not cause pancreas enlargement; but BBTI-TNM caused pancreas enlargement as effectively as native BBTI of RSD.

The effect of native and modified BBTI on pancreatic enzymes was shown in Table 2. The addition of BBTI-Per or BBTI-Mal to HSD showed no significant effect on the level of proteolytic enzymes, whereas in chicks given HSD + BBTI or HSD + BBTI-TNM an increase in the proteolytic enzymes was noted. The amount of amylase and elastase did not change with HSD + BBTI or HSD with supplementation of different modifications.

These findings are compatible with an earlier conclusion that the trypsin inhibitory site is essential for the development of pancreatic enlargement and for increased enzyme activity, whereas the chymotrypsin inhibitory site of BBTI is not involved in any significant effect on the pancreas (Madar et al. 1974).

Previous studies have shown that pancreatic enzyme secretion in the rat is controlled by negative mechanism (Green \& Lyman, 1972; Schneeman \& Lyman, 1975). This has not yet been established in chicks (Madar et al. 1978). The need for active trypsin to be present in the digestive tract in order to suppress enzyme secretion has been indicated by the fact that DFP-trypsin did not suppress enzymes secretion as did the active enzyme (Schneeman \& Lyman, 1975).

Apparently trypsin and chymotrypsin require an accessible active site in order to control enzyme secretion. Modification of the BBTI inhibitory site against trypsin prevents increase of enzymes secretion in the pancreas. This indicates the importance of the inhibitory site of BBTI and of the active site of trypsin for control of enzyme secretion.

\section{REFERENCES}

Birk, Y. (I96I). Biochim. biophys. Acta 54, 378.

Birk, Y. \& Gertler, A. (I968). In Biochemical Preparation, vol. I2, p. 25 [W. E. M. Lands, editor]. New York: Willey.

Birk, Y. \& Gertler, A. (1970). In Proc. int. Res. Congr. Protein Inhibitors, p. 142 [H. Fritz, and H. Tschesche, editors]. Berlin: Walter de Gruyter.

Birk, Y., Gertler, A. \& Khalef, S. (1967). Biochem. biohys. Acta 147, 402.

Bundy, H. (1963). Archs Biochem. Biophys. 102, 416.

Butler, P. I. G., Harris, J. I., Hartley, B. S. \& Leberman, R. (1968). Biochem. J. xr2, 679.

Erlanger, B. F., Kokowsky, N. \& Chon, W. (196I). Archs biochem. Biophys. 95, 27 I.

Gertler, A., Birk, Y. \& Bondi, A. (1967). J. Nutr. 91, 358.

Gertler, A. \& Nitsan, Z. (1970). Br. J. Nutr. 24, 893.

Green, G. M. \& Lyman, R. L. (1972). Proc. Soc. exp. Biol. Med. 140, 6.

Lyman, R. L., Olds, B. A. \& Green, G. M. (1974). J. Nutr. 104, 105. 
Lyman, R. L., Wilcox, S. S. \& Monson, R. R. (I962). Am. J. Physiol. 202, 1077.

Madar, Z., Birk, Y. \& Gertler, A. (1974). Comp. Biochem. Physiol. 48B, 25 I.

Madar, Z., Gertler, A. \& Birk, Y. (1978). Comp. Biochem. Physiol. (In the Press.)

Madar, Z. \& Klein, M. (1978). Nutr. Metab. (In the Press.)

Madar, Z., Tencer, Y., Gertler, A. \& Birk, Y. (1976). Nutr. Metab. 20, 234.

Melmed, R. W., el-Aassar, A. A. A. \& Holt, S. (1976). Biochem. biophys. Acta 421, 280.

Nitsan, Z, \& Gertler, A. (1972). Br. J. Nutr. 27, 337.

Odani, S. \& Ikenaka, T. (1972). J. Biochem. 7r, 839.

Riordan, J. F., Sokolovsky, M. \& Vallee, B. L. (1965). J. Am. Chem. Soc. 88, 4104.

Schneeman, A. B. \& Lyman, R. L. (1975). Proc. Soc. exp. Biol. Med. 148, 897.

Snedecor, G. W. \& Cochran, W. G. (I967). Statistical Methods, 6th ed. Ames, Iowa: The Iowa State College Press. 